\title{
EVALUATION OF DETECTION METHODS FOR COWPEA BACTERIAL BLIGHT CAUSED BY XANTHOMONAS AXONOPODIS PV VIGNICOLA IN NIGERIA
}

\author{
AO Claudius-Cole ${ }^{1 *}$, EJA Ekpo ${ }^{1}$ and AMC Schilder ${ }^{2}$ \\ ${ }^{1}$ Department of Crop Protection and Environmental Biology, University of Ibadan, Nigeria. \\ ${ }^{2}$ Department of Plant, Soil and Microbial Science, Michigan State University, USA.
}

Accepted: 2014 August 15

\begin{abstract}
The detection of cowpea bacterial blight in seed lots of cowpea (Vigna uniguiculata) is important for developing management options. Cowpea seeds were collected from five locations within two agro ecological regions in Nigeria. Various modifications to the plating and soaking methods were adopted to evaluate extraction of bacteria from seeds and selected isolates from the seed lots were subjected to various pathogenicity tests with the objective of find out the best method of detecting the cowpea bacterial blight pathogens in seed lots. All seed assay experiments and pathogenicity tests were laid out in a completely randomized design (CRD) with three replications. Percentage seed infection was significantly higher in Zaria, Minjibir (northern guinea savannah) and Iseyin (forest transition zone) compared to the other production locations in both plating and washing assay methods. The seed coat alone was the most $(p \leq 0.05)$ colonized part of the seed by the pathogen followed by the cotyledons while embryo was the least colonized. Pod inoculation was the most effective pathogenicity test followed by inoculation of young plants, while inoculation of the excised cotyledons, stems and petioles were not reliable in expressing symptoms. Detection of Xanthomonas axonopodis pv vignicola (Xav) is better made with methods that breach the seed coat or using the seed coat alone. Detached pods are just as efficient and takes less time to get results compared to inoculation of young plants for determining pathogenicity of Xav isolates.
\end{abstract}

Key words: Disease detection, Pathogenicity, Seed-borne diseases, Vigna, Xanthomonas

\section{INTRODUCTION}

Cowpea, Vigna unguiculata L. Walp. is one of the most important legume crop grown in the tropical belt of Africa, Asia and South America (Singh et al., 1997). This crop provides food, animal feed and cash for the rural populace in addition to benefits to farmlands via in situ decay of root residues and ground cover due to the spreading habit of the plant. In addition, cowpea grain provides a cheap and nutritious food for relatively poor urban communities (Quin, 1997). Cowpea is cultivated for its grains, leaves, and green pods. The seeds are important in diets for the high protein content providing protein to rural as well as the urban dwellers as a substitute for the animal protein (Wakili, 2013). Worldwide and in Africa, Nigeria ranked first in both production and consumption of cowpea (Adegbite and Amusa, 2008; FAO, 2011). Cowpea's high protein content, its adaptability to different types of soil and intercropping systems, its resistance to drought, and its ability to improve soil fertility

\footnotetext{
*Corresponding author: bi_cole@yahoo.com
}

and prevent erosion makes it an important economic crop in many developing countries.

Increased and intense cultivation of any crop often results in an increase in pest pressure especially in the humid tropics. The major economic diseases of cowpea in the humid agro ecological regions of South-Western Nigeria include brown blotch, anthracnose, cercospora leaf spot, web blight, sclerotium stem blight (Adegbite and Amusa, 2008), cowpea aphidborne mosaic virus, blackeye cowpea mosaic virus and cowpea mosaic virus (Ittah et al., 2010), root-knot nematodes (Onifade and Fawole, 1996) and cowpea bacterial blight and bacterial pustule (Emechebe and Shoyinka, 1985; Okechukwu and Ekpo, 2008).

The important bacterial diseases in Nigeria, cowpea bacterial pustule (CBP) and cowpea bacterial blight (CoBB) are caused by different strains of Xanthomonas axonopodis pv vignicola (Vauterin et al., 1995) (Synonym: $X$. 
campestris pv.vignicola) (Burkholder, 1944). Bacterial blight occurs in all cowpea growing areas of Nigeria (Emechebe and Lagoke, 2002), causing severe grain yield loss of more than $64 \%$ in some areas of West Africa (Sikirou, 1999). When highly susceptible cultivars are sown, the crop may even be completely destroyed (Emechebe and Shoyinka, 1985).

Disease incidence of cowpea bacterial blight is related to the seed borne nature of the pathogen with secondary spread occurring by winddriven rain (COPR, 1981). The bacterium can also survive in soil for up to eight months and in debris for longer periods (Okechukwu and Ekpo, 2008). Symptoms of cowpea bacterial blight on leaves begin with small water-soaked spots, which remain small and, when the adjacent tissues die, gradually coalesce into large, irregular, brown, necrotic lesions surrounded by yellow haloes. The pathogen also invades the stem where it produces cracking with brown stripes, swelling (canker) and form dark green water soaked patches on pods from where it enters the seeds and cause discolouration (Vakili et al., 1975; Kaiser and Ramos, 1979).

The management of the bacterial pathogen can be designed to reduce the multiplication rate at the site of infection on the host plant or to eliminate the inoculum at its source. Measures that affect pathogens at primary sources are more effective (Green, 1994). It is necessary to ascertain the importance of the source in relation to the survival of the pathogen and the initiation of epidemics. A pathogen at its source is more effectively managed when detected early. Detection of the bacterium in seed and quick feedback on pathogenicity has a high impact on disease management options and cost of production. This study evaluated methods of detecting the cowpea bacterial blight pathogens in seed lots.

\section{MATERIALS AND METHODS}

\section{General Laboratory procedure}

Sterilization of glassware was by heat using an oven at $160{ }^{\circ} \mathrm{C}$ for three hours. Metal ware were sterilized by dipping in alcohol and flaming when needed. Media was steam-sterilised with an autoclave at $121^{\circ} \mathrm{C}$ for $15 \mathrm{~min}$ while soil was steam sterilized using a soil sterilizer. Surface sterilization of surfaces was effected with $75 \%$ alcohol while plant material were surface sterilized with $0.5 \%$ sodium hypochlorite $(\mathrm{NaOCl})$. Media used for this study were nutrient agar (NA) by Difco and Yeast dextrose calcium carbonate agar (YDCA).

\section{Isolation of bacteria}

Cowpea leaves showing symptoms of bacterial blight were collected from different fields. The leaves were placed in plastic bags and taken to the laboratory. Surface sterilization with $0.5 \%$ $\mathrm{NaOCl}$ and rinsing in 3 changes of sterile distilled water was done after 1-2 mm leaf pieces were cut at the border of diseased portion. The pieces were ground in a porcelain mortar and pestle in $0.5 \mathrm{ml}$ of sterile distilled water (SDW). Loopfulls of the resulting suspension were streaked on to nutrient agar and incubated at $28{ }^{\circ} \mathrm{C}$ for $48-72$ hours. Pure cultures were made from single colonies of bacteria. The isolates were stored on nutrient agar slants and later used as positive control for other isolates from seed lots.

\section{Inoculum preparation}

Twenty four hour old Xanthomonas axonopodis pv vignicola (Xav) cultures were washed with sterile distilled water using a loop to dislodge the colonies into a beaker. Ten tubes of 10 fold serial dilution were prepared using $1 \mathrm{ml}$ of bacterial suspension to $9 \mathrm{ml}$ of sterile normal saline. Micro dilution plating was done for each dilution on nutrient agar plates and incubated for $24 \mathrm{hrs}$ after which the number of colonies were counted from which the colony forming units per one millilitre $(\mathrm{cfu} / \mathrm{ml})$ was computed as follows.

$\mathrm{Cfu} / \mathrm{ml}=$ no. of colonies $\mathrm{x}$ dilution factor (dilution factor is 100 when micro plating is 
used).

The dilutions were also read for absorbance using a spectrophotometer (Milton Roy) at $640 \mathrm{~nm}$. The graph of absorbance against cfu was plotted and the absorbance reading corresponding to $10^{6}$ cell $\mathrm{s} / \mathrm{ml}$ was noted and subsequently used for estimating inoculum level.

\section{Biochemical and pathogenicity tests on bacterial isolates}

Physiological and biochemical tests were conducted on the bacterial isolates to confirm the identity of the isolates. Potassium hydroxide test was conducted to determine whether the culture is gram negative or gram positive. A clear zone around nutrient agar with $0.2 \%$ soluble starch shows that the bacterium is positive for starch hydrolyses after flooding with iodine (potassium iodide) and negative when agar is stained blue. Oxidation/ fermentation tests were also conducted to determine if the bacterial culture was anaerobic or aerobic. Yellow colour on semi selective Yeast dextrose calcium carbonate agar (YDCA) indicates Xanthomonas spp. Pathogenicity tests were conducted on healthy Ife brown cowpea variety. Inoculum prepared from isolates were sprayed on young, healthy Ife brown cowpea plants, susceptible to Xav (Shoaga, 2001), at $10^{6} \mathrm{cfu} / \mathrm{ml}$ concentration and incubated for $1-14$ days at $28{ }^{\circ} \mathrm{C}$ and $90 \%$ humidity. Presence or absence of characteristic blight symptoms was recorded.

\section{Detection of Xanthomonas axonopodis pv vignicola from seed lots}

Cowpea seeds were collected from fields in Oyo, Kaduna and Kano states in Nigeria. Oyo state is in the forest transition/derived savanna agro ecological zone while Kaduna and Kano states are in the northern guinea savanna. Locations with Oyo state were cowpea production sites in Iseyin (Latitude $7^{\circ} 58^{\prime} \mathrm{N}$; Longitude : $3^{\circ} 36^{\prime} \mathrm{E}$ ), International Institute of
Tropical Agriculture (IITA) Idi -Ose ( $7^{\circ} 30^{\prime}$ 5.1264" N; 3 54' 35.7120" E), Ibadan and Institute of Agricultural Research and Training (IAR\&T) Apata ( $7^{\circ} 22^{\prime} 40.3464^{\prime \prime} \mathrm{N} ; 3^{\circ} 50^{\prime}$ 25.1592" E), Ibadan; Institute of Agricultural Research (IAR), Zaria (11 ${ }^{\circ} 9^{\prime} 33.1488^{\prime \prime} \mathrm{N} ; 7^{\circ}$ $38^{\prime} 52.5768^{\prime \prime} \mathrm{E}$ ), Kaduna and IITA field in Minjibir (latitude $12^{\circ} 03^{\prime} \mathrm{N}$; longitude $08^{\circ} 31^{\prime}$ $\mathrm{E}$,) in Kano. Various modifications of plating and soaking methods (Klement et al., 1990) as described below were evaluated for extraction of bacteria from seeds. For each method three replicates of 100 seeds were surface sterilized in $0.5 \% \mathrm{NaOCl}$ before use and laid out in a completely randomised design.

Direct plating: Seeds were aseptically plated on YDCA after surface sterilization and incubated for $72 \mathrm{hrs}$ and the number of likely Xavinfected seeds were counted. Such colonies were streaked on nutrient agar and subcultured to derive pure cultures. Identification was achieved with biochemical and pathogenicity tests.Component part plating: Seeds were surface sterilised in $0.5 \% \mathrm{NaOCl}$ rinsed in several changes of distilled water then, blotted dry with sterile paper towels. Under aseptic conditions in a laminar flow hood, seed coats, cotyledons and embryos were removed and separately plated on YDCA and incubated for $72 \mathrm{hrs}$. Likely bacteria were streaked on nutrient agar plates to derive pure cultures.

Seedling symptom test: Seeds were planted in plastic trays measuring $60 \times 30 \times 8 \mathrm{~cm}$ containing moist sterilized soil in three replicates. The trays were placed in a humid chamber (Conviron model PGV 36) set at $28{ }^{\circ} \mathrm{C}$ and $90 \%$ RH. Germinating cotyledons were observed after five days for water-soaking and necrotic symptoms and the presence of bacterial ooze. Leaves and stems were also inspected for symptoms for up to 14 days. The number of seedlings showing symptoms were counted and recorded. Isolation and identification of associated bacteria based on symptoms 
was carried out using biochemical and pathogenicity tests.

Long Soak: Three replicates of 100 seeds were surface sterilized and soaked in $50 \mathrm{ml}$ of sterile distilled water (SDW) in a conical flask for 24 hours after which the flask was gently shaken and the supernatant decanted into 50 $\mathrm{ml}$ test tubes. This was then centrifuged at $10,000 \mathrm{rpm}$ for $5 \mathrm{~min}$ to concentrate the bacterial cells at the bottom of the tube. Ten-fold serial dilutions were then made after which micro dilution plating was done. Bacteria were then isolated and identified by biochemical and pathogenicity tests.

Short soak: Three replicates of 100 seeds were surface sterilized and soaked in $50 \mathrm{mls}$ of SDW for $2 \frac{1}{2} \mathrm{hrs}$ while shaking on a rotary shaker at $100 \mathrm{rpm}$ at the room temperature. The liquid decanted was treated as above.

Seed maceration: One hundred seeds in three replicates were surface sterilized, dried and crushed using a sterile mortar and pestle. SDW (100 mls) was added to the crushed seeds in a conical flask and shaken for $30 \mathrm{~min}$ at $100 \mathrm{rpm}$ on a rotary shaker. The mixture was passed through several layers of cotton gauze to remove the seed pieces. The filtrate was centrifuged and treated as above in the long soak method.

\section{Evaluation of pathogenicity tests for rapid detection of Xanthomonas axonopodis pv vignicola}

Selected isolates from the seed lots were subjected to the pathogenicity tests in comparison to conventional pathogenicity tests conducted with plants. These were compared to the originally isolated pathogen which produced symptomatic leaves and with confirmed identities. Completely randomised design was used with three replications.

Spraying of young plants (Conventional method): Healthy Ife brown cowpea seeds were planted in $2 \mathrm{~kg}$ of sterilized soil in plastic pots (12 $\mathrm{cm}$ diameter). Two weeks after planting, inoculation of bacterial isolates was done by spraying $10^{6}$ concentration of bacterial suspension with the aid of an atomizer (Klement et al., 1990). Three leaves were sprayed per plant in three replicates while sterile normal saline was sprayed on control plants. Plants were watered daily for the 14 days during which pathogenic bacteria showed blight symptoms similar to the positive control.

Inoculation of cotyledons: Healthy Ife brown cowpea seeds were sown in trays containing sterilized soil and their cotyledons were removed after 4-5 days. Cotyledons were surface sterilized and stab inoculated in three places, with a needle dipped in bacterial colony for each inoculation. Three cotyledons were inoculated per isolate and sterile distilled water used as the control treatment. These were then placed on moistened filter paper in sterile petri dishes and incubated for 4 days at $28{ }^{\circ} \mathrm{C}$ after which symptoms were observed.

Inoculation of pods: Pods of Ife Brown cowpea were obtained from multiplication plots of the variety at IITA fields. Young tender pods not more that 5 days old were used. Pods were washed, surface sterilised and dried between sterile paper towels, aseptically cut into $5 \mathrm{~cm}$ pieces and placed in petri dishes lined with moistened filter paper. Three pods were placed per petri dish for each isolate. A sterile inoculating pin was used to inoculate young bacterial cultures by stabbing three equidistant points on each pod. These were incubated for 4 days at $28{ }^{\circ} \mathrm{C}$, and symptoms were noted.

Inoculation of stem and petioles: stems and petioles were collected from two-week old healthy Ife brown cowpea plants growing in the screen house. The parts of the stem above the primary leaves along with petioles from the trifoliate leaves were removed. All leaves 
were removed before taking to the laboratory. The stem and petiole pieces were washed, surface sterilized, dried and then cut into $5 \mathrm{~cm}$ pieces. The sections were treated as above.

\section{Data Collection and Statistical methods}

Completely randomised design (CRD) was used for all the experiments. The number of infected seedlings, seed and seed parts were counted and percentage seed infestation was calculated. For liquid assays, percentage infection per 100 seeds was computed. Data collected from host inoculation experiments was analysed using the SAS software for ANOVA and means were separated using least significant difference (LSD) at 5\% level of probability.

\section{RESULTS}

Seed lots from the five locations tested were positive for the presence of Xanthomonas axonopodis pv vignicola. Isolates that did not produce the correct diagnostic results from biochemical tests were discarded. The selected bacteria were negative for gram staining and fermentation, and positive for starch hydrolysis and oxidation and were confirmed as Xav after a positive pathogenicity test on susceptible Ife Brown cowpea plants. Seeds collected from IITA, Ibadan had the lowest percentage seed infection while seeds from farmers' field in Iseyin, Oyo state and Minjibir, Kano had significantly $(\mathrm{P} \leq 0.05)$ high seed infecton (Table 1). The same trend was also observed with the washing methods where bacteria population in seed from Kano and Iseyin farm were higher $(\mathrm{P} \leq 0.05)$ compared to the other seed sources. Of the five plating methods used, plating of the seed coat alone and the seed cotyledons resulted in the highest $(\mathrm{P} \leq 0.05)$ level of seed infection detected while plating the embryo alone gave the lowest infection level for detecting the bacterium in seeds (Table 2). Crushing/ grinding followed by a short soak of the seeds was significantly more efficient $(\mathrm{P} \leq 0.05)$ in detecting the bacterium than either the long or short soak of whole seeds (Table 3 ). The soaking time for whole cowpea seeds did not significantly improve the recovery of the bacterium from whole seeds.

Table 1. Percentage seed infection and population of $X$. axonopodis pv. vignicola in cowpea seeds from different locations

\begin{tabular}{lcc}
\hline $\begin{array}{l}\text { Source of } \\
\text { seeds }\end{array}$ & $\begin{array}{l}\text { Percentage Seed in- } \\
\text { fection (Plating meth- } \\
\text { ods) }\end{array}$ & $\begin{array}{l}\text { Xav population } \\
\text { (Washing method } \\
\left(10^{6} \mathrm{cfu}\right)\end{array}$ \\
\hline $\begin{array}{l}\text { IITA, } \\
\text { Ibadan }\end{array}$ & $7.8 \mathrm{c}$ & $4.6 \mathrm{c}$ \\
$\begin{array}{l}\text { IAR\&T, } \\
\text { Ibadan }\end{array}$ & $12.5 \mathrm{bc}$ & $6.2 \mathrm{c}$ \\
$\begin{array}{l}\text { Iseyin } \\
\text { farm }\end{array}$ & $19.3 \mathrm{ab}$ & $12.4 \mathrm{~b}$ \\
$\begin{array}{l}\text { Minjibri, } \\
\text { Kano }\end{array}$ & $23.6 \mathrm{a}$ & $18.7 \mathrm{a}$ \\
$\begin{array}{l}\text { Zaria, } \\
\text { Kaduna }\end{array}$ & $25.3 \mathrm{a}$ & $20.7 \mathrm{a}$ \\
$\begin{array}{l}\text { LSD } \\
(0.05)\end{array}$ & 7.2 & 5.4 \\
\hline
\end{tabular}

Values are means of three replicates. Means with the same letters in a column are not significantly different at $\mathrm{P} \leq 0.05$ using LSD.

Table 2. Percentage infected seeds from plating methods compared to seedling symptom test

\begin{tabular}{lll}
\hline $\begin{array}{l}\text { Detection } \\
\text { Method }\end{array}$ & $\begin{array}{l}\text { Percentage seed } \\
\text { infection }\end{array}$ \\
\hline Direct plating & Whole seed & $14.2 \mathrm{~cd}$ \\
$\begin{array}{l}\text { Component } \\
\text { part plating }\end{array}$ & Embryo & $10.0 \mathrm{de}$ \\
& Cotyledons & $19.2 \mathrm{ab}$ \\
& Seed coat & $22.5 \mathrm{a}$ \\
& $\begin{array}{l}\text { Seedling symptom } \\
\text { test }\end{array}$ & $16.7 \mathrm{bc}$ \\
& & 4.7 \\
\hline
\end{tabular}

Values are means of three replicates. Means with the same letters are not significantly different at $\mathrm{P} \leq 0.05$ using LSD.

Inoculated pods had the highest percentage symptoms expressed $(89 \%)$ followed by leaves of young plants $(62.8 \%)$ but they were not significantly different from each other (Table 4). Percentage symptom expression from inoculated excised cotyledons though significantly lower than percentage expression from pods was not significantly different from 
the symptom expression in leaves of cowpea plants. Inoculated pods and leaves of whole plants were significantly $(\mathrm{P} \leq 0.05)$ more reliable in showing symptoms and expressed symptoms more frequently than petioles and stems. The bacterium elicited different symptoms on the parts of the plant inoculated. Characteristic leaf blight symptoms were observed on young plants beginning with water soaked spots which turned chlorotic and then necrotic with spots around the leaf margin coalescing to form large blighted areas. The stems and petioles that expressed symptoms showed water soaking around the stab area which later turned necrotic. However, most of the stems and petioles did not express symptoms. Cotyledons showed symptoms of water soaking first, followed by brown discolouration. Bacterial ooze was observed from some stab punctures at the advanced stage. Pods also showed symptoms of water soaking in the initial stage which later turned brown and the tissue then collapsed.

Table 3. Population of Xanthomonas axonopidis pv vignicola detected using different soaking methods

\begin{tabular}{rr}
\hline Soaking Method & $\begin{array}{r}\text { Bacterial concentration per 100 } \\
\text { seeds }\left(\times 10^{5} \mathrm{cfu}\right)\end{array}$ \\
\hline Long soak (24 hrs) & $1.5 \mathrm{~b}$ \\
Short soak (2.5 hrs) & $1.6 \mathrm{~b}$ \\
Crushing with 30 min & $13.4 \mathrm{a}$ \\
shaking & 10.5 \\
LSD & \\
\hline
\end{tabular}

Values are means of three replicates. Means with the same letters are not significantly different at $\mathrm{P} \leq 0.05$ using LSD.

Table 4. Percentage of inoculation points showing symptoms on whole plants and detached plant parts

\begin{tabular}{|l|l|l|}
\hline $\begin{array}{l}\text { Method of inocu- } \\
\text { lation }\end{array}$ & $\begin{array}{l}\text { \%of inoculation } \\
\text { points with symptom }\end{array}$ & $\begin{array}{l}\text { Time taken for } \\
\text { complete results } \\
\text { (days) }\end{array}$ \\
\hline Stem & $13.2 \mathrm{bc}$ & $6 \mathrm{~b}$ \\
\hline Petioles & $11.1 \mathrm{c}$ & $6 \mathrm{~b}$ \\
\hline $\begin{array}{l}\text { Excised cotyle- } \\
\text { dons }\end{array}$ & $42.2 \mathrm{~b}$ & $5 \mathrm{~b}$ \\
\hline Whole plants & $62.8 \mathrm{ab}$ & $28 \mathrm{a}$ \\
\hline Pods & $89.4 \mathrm{a}$ & $5 \mathrm{~b}$ \\
\hline LSD $_{(0.05)}$ & 33.5 & 10.1 \\
\hline
\end{tabular}

Values are means of three replicates. Means with the same letters are not significantly different at $\mathrm{P} \leq 0.05$ using LSD.

\section{DISCUSSION}

Seed-borne inoculum of many diseases is inconspicuous and is generally undetectable by direct inspection or even by observation under low power stereomicroscopes. The importance of seed-borne pathogens to crop quality and quantity cannot be ignored. Reduced germination, poor plant performance and disease carry over are some of the implications of planting disease-infected seeds (Nafula, 2010). The higher infection of Xanthomonas axonopodis pv vignicola of cowpea seed lots collected from Kano may be because the fields had been cropped to cowpea several times resulting in a build up of inoculum over time. This also applies to the farmers' field in Iseyin in combination with the possibility that the source of seed used was the farmers saved seed that may have carried over inoculum. Xanthomonas axonopodis pv vignicola was demonstrated to survive in soil for up to eight months while plant debris and seeds are the major way of pathogen survival between seasons (Okechukwu and Ekpo, 2008). The seed is also the major means by which the pathogen is spread over long distances (Amodu, 2013).

The seedling symptom test is often the most common method for detecting pathogens in seed but the time it takes to obtain results is much longer and requires more space than the plating methods. The presence of higher percentage infection on the seed coat and cotyledons indicate that the bacterium is concentrated beneath the seed coat where surface sterilization was unable to affect it. This has implication for the management of the disease. Seed treatment methods such as hot water therapy at $50-55{ }^{\circ} \mathrm{C}$ for $20 \mathrm{~min}$, or hot air treatment at $40-45^{\circ} \mathrm{C}$ (Miller and Lewis-Ivey, 2005 ) would significantly reduce disease incidence and severity without damaging the embryo. Seed treatment with biological agents will also be additionally effective. Testing from a small lot of seeds can also be made more representative, if testing for the patho- 
gen is done using only the seed coat, leaving the seed for other tests such as germination or vigour. This method when compared to the traditional seedling symptom test provides results in a shorter period. Amodu (2013) demonstrated that the hilum was the most colonized part of the seed, this corroborates the findings of this study; the seed coat and cotyledons are joined with the hilum and bacteria found in and around the hilum will be found in the seed coat and cotyledons. The study of Amodu (2013) also demonstrated similar to our findings that the embryo of cowpea seeds was the least colonised.

The soaking method involving shaking crushed seeds in water for $30 \mathrm{~min}$ extracted significantly higher populations of bacteria from the seeds compared to the other soaking methods used. This further confirms that the cowpea bacterial blight (CoBB) pathogen is better detected below the seed coat and on the cotyledons. This implies that the bacterium can escape detection when in low densities on seed if other soaking methods are used. Generally, methods that do not breach the seed coat may not be able to detect the bacterium (Xav) at low populations.

Pathogenicity studies are usually conducted on shoots (leaves and stem) of young plants growing in pots, however this usually takes at least three weeks. Using pods or cotyledons considerably shortens the period in which results can be obtained by as much as $80 \%$ as these results can be ready within 1 week. While testing lines for resistance to common blight of beans, detached pods were found to provide similar results as leaves of young plants and pods also provided the additional advantage of being amenable to use in small spaces and reduces environmental variance (Ariyarathne et al., 1998). Cotyledons were also as good as seedlings in symptom expression and can also be used. They have the additional advantage of being even smaller than pods. In addition cotyledons can be made more readily available as pods are produced from mature plants. The low symptom expression in detached stems and petioles is probably due to the ability of excised stem of cowpea to form callous tissue, which may prevent the invasion of bacterial cells. Canker symptoms however develop in stems of young plants when inoculated (Okechukwu and Ekpo, 2008).

Early identification and listing of plant pathogens in an area allows for early and timely development of control and management strategies that goes a long way in avoiding epidemics and crop losses. At the same time, laboratory screening of seeds before sowing is a cheap and effective means of checking the spread of many seed-borne diseases, if correctly carried out and is a sure way of arresting spread of diseases to new areas. The methods suggested by this study provide accurate results compared to some conventional methods while shortening the time for providing results to end users. This has an implication for quarantine services as well as extension and advisory services. Plating of whole seeds or cotyledons and crushing plus soaking of cowpea seeds are efficient methods for detecting $X$. axonopodis pv vignicola in seed lots.

\section{REFERENCES}

Adegbite, AA and Amusa NA 2008The major economic field diseases of cowpea in the humid agro-ecologies of SouthWestern Nigeria. Afr. J Biotech., 7.(25): 4706-4712.

Amodu US 2013 Mechanisms of seed transmission of bacterial blight of cowpea (Xanthomonas axonopodis pv. vignicola) (Burkholder) Dye. Ph.D thesis Crop Protection, Department of Crop Protection, Faculty of Agriculture, Ahmadu Bello University, Zaria. $183 \mathrm{pp}$.

Ariyarathne HM, Coyne DP, Vidaver AK and 
Eskridge, KM 1998 Selecting for common bacterial blight resistance in common bean: Effects of multiple inoculation and detached pod inoculation test. J. American Soc. of Hort. Sc. 123(5): 864-867.

Buekholder WH 1944 Xanthomonas vignicola sp. Nov. pathogenic on cowpeas and beans. Phytopathology 34:430-432.

Centre for Overseas Pest Research (COPR) 1981 Pest control in tropical grain legumes. COPR, London, UK.

Emechebe AM and Shoyinka SA 1985 Fungal and bacterial diseases of cowpeas in Africa. Pp.173-197. In: Singh SR and KO Rachie (eds) Cowpea research, production and utilization. John Wiley \& Sons Ltd., UK.

Emechebe AM, and Lagoke STO 2002 Recent advances in research on cowpea diseases. pp 94-123.In: Fatokun CA, Tarawali SA, Singh BB, Kormawa PM, Tamo M (eds) Challenges and opportunities for enhancing sustainable cowpea production. Proceedings of the World Cowpea Conference III held at the International Institute of Tropical Agriculture (IITA), Ibadan, Nigeria, 4-8 September 200. IITA, Ibadan Nigeria.

Food and Agricultural Organisation (FAO) 2011 accessed on June 2013. http:// faostat.fao.org/site/339/default.aspx

Green KR 1994 Studies on the epidemiology and control of yam anthracnose. $\mathrm{PhD}$ thesis, University of Reading, UK. 190 pp.

Ittah MA, Fawole I, Shoyinka SA, and Hughes JD 2010 Response of cowpea lines to inoculation with four seed transmitted viruses of cowpea. Glb J Agric. Sci. 9 (1): 27-33

Kaiser WJ and Ramos AH 1979 Two bacteria diseases of cowpea in East Africa. Plant Dis. Rep. 63: 304-308.

Klement Z, Rudolph K and DC Sands 1990 Methods in phytobacteriology. Akadéma Kiadó, Buda-pest. 547pp.

Miller SA and Lewis Ivey M L 2005 Hot Wa- ter and Chlorine Treatment of Vegetable Seeds to eradicate Bacterial Plant Pathogens. Ohio State Extension Fact sheet. Ohio State University 5pp.

Nafula MM 2010 Assessment of seed-borne pathogens for some important crops in western Kenya.12 ${ }^{\text {th }}$ KARI scientific conference proceedings held at KARIKatumani, Machakos, Kenya. Pp747753

Okechukwu RU and Ekpo EJA 2008 Survival of Xanthomonas campestris pv. vignicola in infested soil, cowpea seed and cowpea debris. Trop Agric. Res. and Extension 11: 43-48

Onifade AK and Fawole B 1996 Effect of some plant extracts on the pathogenicity of Meloidogyne incognita on cowpea. Global J. Pure Appl. Sci. 2: 9-15.

Quin FM 1997 Importance of Cowpea p. 375 -388. In: Singh, BBm Dashiell KE, Mohan Raj DR and Jackai LEN (Eds.), Advances in Cowpea Research Colcorcraft, Hong Kong,

Shoaga OA, Ekpo EJA and Okechukwu RU 2001 Comparative virulence of bacterial blight (Xanthomonas campestris pv vignicola) isolates and their effect on yield components of cowpea (Vigna uguiculata). Trop Agric. Res. and Extension 4(2): 76-80.

Sikirou R 1999 Epidemiological investigations and development of integrated control methods of bacterial blight of cowpea caused by Xanthomonas campestris pv. vignicola. $\mathrm{PhD}$ thesis. University of Göttingen, Germany. p. 218.

Singh BB, Chambliss OL and Sharma B 1997 Recent advances in cowpea breeding $p p$ 30-49. In: Singh BB, Mohan Raj DR, Dashiell KE, Jackai LEN (eds) Advances in cowpea research. IITA and Japan International Research Centre for Agricultural Sciences (JIRCAS), Ibadan, Nigeria,

Vakili NG, Kaiser WJ, Perez JA and CortesMonllor A 1975 Bacteria blight of 
beans caused by two Xanthomonas pathogenic types from Puerto Rico. Phytopathol. 65: 401-403.

Vauterin L, Hoste B, Kersters K and Swings J 1995 Reclassification of Xanthomonas. Int J System Bacteriol. 45:472-489.

Wakili AM 2013 Economic analysis of cowpea production in Nigeria. Russian J. of Agric. and Socio-Economic Sci, 1(13): $60-63$. 